\title{
ABOUT NONUNIQUENESS OF SOLUTIONS OF THE SHOWALTER- SIDOROV PROBLEM FOR ONE MATHEMATICAL MODEL OF NERVE IMPULSE SPREAD IN MEMBRANE
}

\author{
N.A. Manakova ${ }^{1}$, O.V. Gavrilova ${ }^{1}$ \\ ${ }^{1}$ South Ural State University, Chelyabinsk, Russian Federation \\ E-mails: manakovana@susu.ru, gavrilovaov@susu.ru
}

\begin{abstract}
The article is devoted to the study of the morphology of the phase space of a mathematical model of the nerve impulse spread in a membrane, based on a degenerate Fitz Hugh-Nagumo system, defined on a bounded domain with a smooth boundary. In this mathematical model, the rate of change of one of the components of the system can significantly exceed the other, which leads to a degenerate Fitz Hugh-Nagumo system. The model under inquiry belongs to a wide class of semilinear Sobolev type models. To research the problem of nonuniqueness of solutions of the Showalter-Sidorov problem, the phase space method will be used, which was developed by G.A. Sviridyuk to scrutinize the solvability of Sobolev type equations. We have shown that the phase space of the studied model contains singularity such as the Whitney fold. The conditions of existence, uniqueness or multiplicity of solutions of the Showalter-Sidorov problem depending on the parameters of the system are found.
\end{abstract}

Keywords: Sobolev type equations; Showalter-Sidorov problem; Fitz Hugh-Nagumo system; nonuniqueness of the solution.

Dedicated to Professor Viktor Chistyakov on the occasion of his 70th birthday.

\section{Introduction}

An important part of the development of modern biophysics is the study of mathematical models of processes in living nature. Processes such as blood clotting, nerve impulse spreading, cardiac muscle contraction can be modelled using the Fitz HughNagumo system of equations [1,2]:

$$
\left\{\begin{array}{l}
\epsilon_{1} v_{t}=\alpha_{1} v_{s s}+\beta_{1} w-\kappa_{1} v \\
\epsilon_{2} w_{t}=\alpha_{2} w_{s s}+\beta_{2} w-\kappa_{2} v-w^{3}
\end{array}\right.
$$

where parameters $\alpha_{1}, \alpha_{2}, \beta_{1}, \kappa_{1} \in \mathbb{R}_{+}, \beta_{2}, \kappa_{2} \in \mathbb{R}, \epsilon_{1}, \epsilon_{2} \geq 0$. System (1), on the one hand, is the development of the classical Kolmogorov-Petrovsky-Piskunov model, and on the other hand, some simplified version of the Hodgkin-Huxley model, which plays a significant role in the theory of nerve conduction. However, the majority of researchers considered the system of equations (1) under the assumption of $\epsilon_{1}, \epsilon_{2} \neq 0[3,4]$. At the same time, cases of degenerate systems $\left(\epsilon_{1}=0\right.$ or $\left.\epsilon_{2}=0\right)$ remained poorly understood, the necessity of studying of which is connected with the fact that the rate of change of one of the components of system (1) can significantly exceed another one. In case of $\epsilon_{1}=0$, the phase space of the system is a simple Banach $C^{\infty}$-manifold, therefore, the problem has a unique solution. The question of the solvability of the Showalter-SidorovDirichlet problem for Fitz Hugh-Nagumo system (1) in the case $\epsilon_{1}=0$ was considered in 
papers [5,6], it was also studied their optimal control, start control and final observations for this system. In this article, we will be interested in case of $\epsilon_{2}=0$. In this case, the phase space of system of equations (1) contains singularity of Whitney fold type [7], which leads to nonuniqueness of solutions.

Consider degenerate system of equations (1) in case $\epsilon_{2}=0$ in cylinder $Q=\Omega \times \mathbb{R}_{+}$, where $\Omega \subset \mathbb{R}^{n}$ is a bounded domain with boundary $\partial \Omega$ of class $C^{\infty}$ :

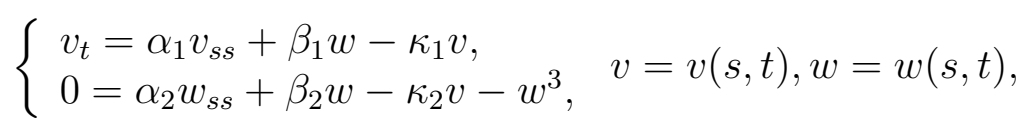

with boundary value conditions

$$
v(s, t)=0, w(s, t)=0,(s, t) \in \partial \Omega \times \mathbb{R}_{+},
$$

and initial value condition

$$
v(0)=v_{0}
$$

Problem (2) - (4) can be investigated within the framework of abstract Showalter-Sidorov problem

$$
L\left(u(0)-u_{0}\right)=0
$$

for semilinear Sobolev type equation

$$
L \dot{u}=M u+N(u), \operatorname{ker} L \neq\{0\}
$$

in specially constructed function spaces. Here $L \in \mathcal{L}(\mathfrak{U}, \mathfrak{F}), M \in \mathcal{C l}(\mathfrak{U} ; \mathfrak{F}), N$ is nonlinear operator, $\mathfrak{U}, \mathfrak{F}$ are Banach spaces. By the phase space of equation (6) we mean the closure of the set of all admissible initial values, for which there is a local solution to problem $(5),(6)[8]$. So, based on the theory of $(L, p)$-bounded operators or $(L, p)$-sectorial operators, G.A. Sviridyuk, and later his adherers [9,10], found the conditions for the unique solvability of problem (5), (6). Namely, when the operator $M$ is $(L, p)$-sectorial (bounded) and the phase space of equation (6) is a simple Banach $C^{\infty}$-manifold, there is a single quasistationary the (semi)trajectory of problem (5), (6) passing through point $u_{0}$, which lies pointwise in phase space [11]. Recall that Banach $C^{\infty}$-manifold is called simple if any of its atlas is equivalent to an atlas containing a single chart. In particular, if operator $M$ is $(L, 0)$-sectorial (bounded), then any solution (5), (6) will be a quasistationary (semi)trajectory. The main method for studying problem $(2)-(4)$ is the phase space method. Following it, we construct set $\mathfrak{M}=\{u \in \mathfrak{U}:(I-Q)(M u+N(u))=0\}$, then all solutions of problem (1), (3) lie in set $\mathfrak{M}$ as trajectories, where $Q$ is spectral projector [11].

Back in 1987, G.A. Sviridyuk suggested that the solution to problem (5), (6) may not be unique if phase space of equation (6) is not simple Banach $C^{\infty}$-manifold. In review [12] it was shown that initial value condition (5) for (6) can have several solutions in cases where phase space of (6) lies on smooth Banach manifold having singularities such as Whitney folds. For example, the Showalter-Sidorov problem for the Korpusov-Pletner-Sveshnikov equation may have two different solutions [13], and for the system of Plotnikov equations - three [14]. In work [7] it was shown that in degenerate case (for $\epsilon_{2}=0$ ) phase space of (2) contains singularity such as Whitney folds, therefore, it can have one or more solutions or the solution may not exist. In the course of this study, we will identify the conditions for the existence and uniqueness or multiplicity of solutions of Showalter-Sidorov problem (4) for Fitz Hugh-Nagumo system (2) depending on the parameters of the system. 


\section{The Morphology of Phase Space}

Let $\Omega \subset \mathbb{R}^{n}$ be a bounded domain with boundary $\partial \Omega$ of class $C^{\infty}$. In cylinder $Q=$ $\Omega \times \mathbb{R}_{+}$we consider system of equations (2) with boundary value conditions (3) and initial value condition (4). We set $\mathfrak{H}_{i}=W_{2}^{1}(\Omega), i=1,2$ and define space

$$
\mathfrak{H}=\mathfrak{H}_{1} \times \mathfrak{H}_{2}=W_{2}^{1}(\Omega) \times W_{2}^{1}(\Omega) .
$$

Let vector functions $u=(v, w), \zeta=(\xi, \eta)$, consider Hilbert space $\mathcal{H}=L_{2}(\Omega) \times L_{2}(\Omega)$ with scalar product

$$
[u, \zeta]_{\mathcal{H}}=\langle v, \xi\rangle_{\mathfrak{H}_{1}}+\langle w, \eta\rangle_{\mathfrak{H}_{2}},
$$

and space $\mathfrak{U}_{N}=L_{4}(\Omega) \times L_{4}(\Omega)$. By $\mathfrak{U}=\mathfrak{F}$ we denote the space adjoint to $\mathfrak{H}$ with respect to duality of $[\cdot, \cdot]$ in $\mathcal{H}$. By virtue of the Sobolev embedding Theorems there are dense and continuous embeddings

$$
\mathfrak{H} \hookrightarrow \mathfrak{U}_{N} \hookrightarrow \mathcal{H} \hookrightarrow \mathfrak{U}_{N}^{*} \hookrightarrow \mathfrak{U}=\mathfrak{F} .
$$

Note that space $\mathcal{H}$ is identified with its adjoint. Construct linear operators $L, M: \mathfrak{U} \rightarrow \mathfrak{F}$

$$
\begin{gathered}
{[L u, \zeta]=\langle v, \xi\rangle, u, \zeta \in \mathfrak{U},} \\
{[M u, \zeta]=-\alpha_{1}\left\langle v_{s_{i}}, \xi_{s_{i}}\right\rangle-\alpha_{2}\left\langle w_{s_{i}}, \eta_{s_{i}}\right\rangle, u, \zeta \in \mathfrak{U}, \text { where } \operatorname{dom} M=\mathfrak{H}}
\end{gathered}
$$

and nonlinear operator

$$
[N(u), \zeta]=\left\langle\beta_{1} w-\kappa_{1} v, \xi\right\rangle+\left\langle\beta_{2} w-\kappa_{2} v-w^{3}, \eta\right\rangle, \text { where } \operatorname{dom} N=\mathfrak{U}_{N} .
$$

(Note that the Einstein agreement on summation over repeated indices is fulfilled everywhere.) By construction, operator $L \in \mathcal{L}(\mathfrak{U}, \mathfrak{F}), M \in \mathcal{C} l(\mathfrak{U} ; \mathfrak{F})$.

Denote by

$$
\begin{gathered}
\mathfrak{U}^{0}=\operatorname{ker} L=\{0\} \times W_{2}^{-1}(\Omega), \mathfrak{U}^{1}=W_{2}^{-1}(\Omega) \times\{0\}, \\
\mathfrak{F}^{1}=\operatorname{im} L=W_{2}^{-1}(\Omega) \times\{0\}, \mathfrak{F}^{0}=M\left[\mathfrak{U}^{0} \cap \operatorname{dom} M\right]=\{0\} \times W_{2}^{-1}(\Omega),
\end{gathered}
$$

when $\mathfrak{U}=\mathfrak{U}^{0} \oplus \mathfrak{U}^{1}, \mathfrak{F}=\mathfrak{F}^{0} \oplus \mathfrak{F}^{1}$. Set $L_{1}$ as the restriction of operator $L$ to $\mathfrak{U}^{1}$, then $L_{1}^{-1} \in \mathcal{L}\left(\mathfrak{F}^{1}, \mathfrak{U}^{1}\right)$.

Lemma 1. For any $\alpha_{1}, \alpha_{2} \in \mathbb{R}_{+}, \beta_{1}, \beta_{2}, \kappa_{1}, \kappa_{2} \in \mathbb{R}, n \leq 4$

(i) the operator $M$ is (L,0)-sectorial;

(ii) $N \in C^{1}\left(\mathfrak{U}_{N} ; \mathfrak{U}_{N}^{*}\right)$.

Proof. (i) $(L, 0)$-sectoriality operator $M$ was shown in work [14].

(ii) We show that $N \in C^{1}\left(\mathfrak{U}_{N} ; \mathfrak{U}_{N}^{*}\right)$, where $\mathfrak{U}_{N}^{*}$ is dual space of $\mathfrak{U}_{N}$ with respect to duality of $[\cdot, \cdot]$. Indeed, due to Hölder inequality, we have

$$
\begin{gathered}
|[N(u), \zeta]| \leq\left(C_{1}|| u\left\|_{\mathfrak{U}_{N}}^{3}+C_{2}|| u\right\|_{\mathfrak{U}_{N}}\right)\|\zeta\|_{\mathfrak{U}_{N}}, \\
\left|\left[N_{u}^{\prime} \zeta_{1}, \zeta_{2}\right]\right|=\left|\int_{\Omega}\left(\beta_{1} \xi_{1} \xi_{2}-\kappa_{1} \xi_{1} \xi_{2}\right) d s+\int_{\Omega}\left(\beta_{2} \eta_{1} \eta_{2}-\kappa_{2} \eta_{1} \eta_{2}-3 w^{2} \eta_{1} \eta_{2}\right) d s\right| \leq \\
\leq\left(C_{3}|| u \|_{\mathfrak{U}_{N}}^{2}+C_{4}\right) \cdot\left\|\zeta_{1}||_{\mathfrak{U}_{N}} \cdot\right\| \zeta_{2} \|_{\mathfrak{U}_{N}},
\end{gathered}
$$

where constants $C_{i} \in \mathbb{R}_{+}, i=\overline{1,4}$, depend neither on $u$, nor on $\zeta, \zeta_{1}, \zeta_{2}$. Here $N_{u}^{\prime}$ is the Frechet derivative of operator $N$ at point $u$. The inclusion of $N \in C^{1}\left(\mathfrak{U}_{N} ; \mathfrak{U}_{N}^{*}\right)$ is proved. 
Thus, we reduced problem (2), (3) to a semilinear equation of Sobolev type (6). Note that condition (4) takes form (5). We are interested in the solvability of problem (2) - (4) for any $u_{0}=\left(v_{0}, w_{0}\right) \in \mathfrak{H}$.

Let $\left\{\nu_{k}\right\}$ denote the sequence of eigenvalues of the following spectral problem:

$$
\begin{aligned}
-\Delta \varphi & =\nu \varphi, s \in \Omega, \\
\varphi(s) & =0, s \in \partial \Omega,
\end{aligned}
$$

where eigenvalues are numbered in nondecreasing order of their multiplicity. Denote by $\left\{\varphi_{k}\right\}$ the corresponding eigenfunctions orthonormal in the sense of scalar product $\langle\cdot, \cdot\rangle$ in $L_{2}(\Omega)$.

Definition 1. Vector-function $u \in C^{1}((0, \tau) ; \mathfrak{U}) \cap C\left((0, \tau) ; \mathfrak{U}_{N}\right)$, satisfying equation (2), is called the solution of the equation. Solution $u=u(t)$ of equation (2) is called the solution of problem (2), (4) if

$$
\lim _{t \rightarrow 0+}\left\|L\left(u(t)-u_{0}\right)\right\|_{\mathfrak{F}}=0 .
$$

Build

$$
\mathfrak{M}=\left\{u \in \mathfrak{H}:-\langle v, \eta\rangle=\left\langle-\frac{\beta_{2}}{\kappa_{2}} w+\frac{1}{\kappa_{2}} w^{3}, \eta\right\rangle+\left\langle\frac{\alpha_{2}}{\kappa_{2}} w_{s_{i}}, \eta_{s_{i}}\right\rangle\right\}
$$

and note that all solutions of system of equations (2) satisfying boundary value conditions (3) will lie in this set.

Lemma 2. Let $\alpha_{2}, \kappa_{2} \in \mathbb{R}_{+}, \beta_{2} \in\left(0, \alpha_{2} \nu_{1}\right), n \leq 4$, then for any vector $v \in \mathfrak{H}_{1}$ there exists unique vector $w \in \mathfrak{H}_{2}$ such that $u=\operatorname{col}(v, w) \in \mathfrak{M}$.

Proof. Construct an auxiliary operator

$$
\langle A(w), \eta\rangle=\left\langle-\frac{\beta_{2}}{\kappa_{2}} w+\frac{1}{\kappa_{2}} w^{3}, \eta\right\rangle+\left\langle\frac{\alpha_{2}}{\kappa_{2}} w_{s_{i}}, \eta_{s_{i}}\right\rangle, w, \eta \in \mathfrak{H}_{2}, \operatorname{dom} A=\mathfrak{H}_{2} .
$$

Denote by $\mathfrak{H}_{2}^{*}$ the space conjugate to $\mathfrak{H}_{2}$ with respect to duality of $\langle\cdot, \cdot\rangle$. Insofar as

$$
\left|\left\langle A\left(w_{1}\right), w_{2}\right\rangle\right| \leq C_{1}\left(|| w_{1}\left\|_{\mathfrak{H}_{2}}+\right\| w_{1} \|_{\mathfrak{H}_{2}}^{3}\right)|| w_{2} \|_{\mathfrak{H}_{2}}
$$

where constant $C_{1} \in \mathbb{R}_{+}$depends on $\beta_{2}, \kappa_{2}, \alpha_{2}$ and embedding constants (7) and does not depend on $w$, thus the action of operator $A: \mathfrak{H}_{2} \rightarrow \mathfrak{H}_{2}^{*}$ is proved. Note that operator $A: \mathfrak{H}_{2} \rightarrow \mathfrak{H}_{2}^{*}$ is coercive, i.e.

$$
\begin{gathered}
\lim _{\|w\|_{\mathfrak{H}_{2}} \rightarrow+\infty}\langle A(w), w\rangle\|w\|_{\mathfrak{H}_{2}}^{-1}=\lim _{\|w\|_{\mathfrak{H}_{2}} \rightarrow+\infty}\left(\int_{\Omega}\left(-\frac{\beta_{2}}{\kappa_{2}} w^{2}-\frac{\alpha_{2}}{\kappa_{2}}\left(w_{s_{i}}\right)^{2}+\frac{1}{\kappa_{2}} w^{4}\right) d s\right) . \\
\cdot\left(\int_{\Omega}\left(w_{s_{i}}^{2}+w^{2}\right) d s\right)^{-\frac{1}{2}}=+\infty .
\end{gathered}
$$

In addition, operator $A$ is strictly monotone, that is,

$$
\begin{gathered}
\left\langle A\left(w_{1}\right)-A\left(w_{2}\right), w_{1}-w_{2}\right\rangle=\int_{\Omega}\left(-\frac{\beta_{2}}{\kappa_{2}}\left(w_{1}-w_{2}\right)^{2}-\frac{\alpha_{2}}{\kappa_{2}}\left(w_{1_{s_{i}}}-w_{2_{s_{i}}}\right)^{2}+\right. \\
\left.+\frac{1}{\kappa_{2}} \cdot\left(w_{1}-w_{2}\right)^{2}\left(w_{1}^{2}+w_{1} w_{2}+w_{2}^{2}\right)\right) d s>0 \forall w_{1}, w_{2} \in \mathfrak{H}_{2},
\end{gathered}
$$

as soon as $w_{1} \neq w_{2}$. Finally, we show the smoothness of operator $A$. Indeed, 


$$
\left|\left\langle A_{w}^{\prime} \xi, \eta\right\rangle\right|=\left|\int_{\Omega}\left(-\frac{\beta_{2}}{\kappa_{2}} \eta \xi-\frac{\alpha_{2}}{\kappa_{2}} \eta_{s_{i}} \xi_{s_{i}}+\frac{1}{\kappa_{2}} 3 w^{2} \eta \xi\right) d s\right| \leq\left(C_{1}+C_{2}\|w\|_{\mathfrak{H}_{2}}^{2}\right)\|\eta\|_{\mathfrak{H}_{2}}|| \xi \|_{\mathfrak{H}_{2}},
$$

where constants $C_{1}, C_{2}$ depend only on $\alpha_{2}, \beta_{2}, \kappa_{2}$ and the nesting constants. Hence, by virtue of the Vishik-Minty-Browder Theorem [15], equation $A(w)=-v$ has a unique solution.

Consider the case of $\beta_{2}=\alpha_{2} \nu_{1}$, put

$$
\mathfrak{H}_{1}^{\perp}=\left\{v^{\perp} \in \mathfrak{H}_{1}:\left\langle v^{\perp}, \varphi\right\rangle=0\right\}, \mathfrak{H}_{2}^{\perp}=\left\{w^{\perp} \in \mathfrak{H}_{2}:\left\langle w^{\perp}, \varphi\right\rangle=0\right\} .
$$

Let $\nu_{1}$ be a single root and $\varphi$ be an eigenfunction of problem (8), corresponding to the eigenvalue of $\nu_{1}$, normalized in sense $L_{2}(\Omega)$. If $v \in \mathfrak{H}_{1}$ and $w \in \mathfrak{H}_{2}$ be represented as $v=v^{\perp}+r \varphi$ and $w=w^{\perp}+q \varphi$, where $r, q \in \mathbb{R}$, then set $\mathfrak{M}$ takes the following form:

$$
\mathfrak{M}=\left\{u \in \mathfrak{H}:\left\{\begin{array}{l}
-v^{\perp}=-\frac{\beta_{2}}{\kappa_{2}} w^{\perp}-\frac{\alpha_{2}}{\kappa_{2}} \Delta w^{\perp}+\frac{1}{\kappa_{2}} \int_{\Omega}\left(w^{\perp}+q \varphi\right)^{3} \varphi d s, \\
-\kappa_{2} r=\int_{\Omega}\left(w^{\perp}+q \varphi\right)^{3} \varphi d s .
\end{array}\right\} .\right.
$$

Lemma 3. Let $\alpha_{2}, \kappa_{2} \in \mathbb{R}_{+}, \beta_{2}=\alpha_{2} \nu_{1}, n \leq 4$, then for any vector $v^{\perp} \in \mathfrak{H}_{1}^{\perp}$ there exists unique vector $w^{\perp} \in \mathfrak{H}_{2}^{\perp}$ such that

$$
v^{\perp}=\frac{\beta_{2}}{\kappa_{2}} w^{\perp}+\frac{\alpha_{2}}{\kappa_{2}} \Delta w^{\perp}-\frac{1}{\kappa_{2}} \int_{\Omega}\left(w^{\perp}+q \varphi\right)^{3} \varphi d s .
$$

The proof of this lemma is carried out similarly to the proof of Lemma 2, if we consider the following operator as an auxiliary operator:

$$
A\left(w^{\perp}\right)=\frac{-\beta_{2}}{\kappa_{2}} w^{\perp}-\frac{\alpha_{2}}{\kappa_{2}} \Delta w^{\perp}+\frac{1}{\kappa_{2}} \int_{\Omega}\left(w^{\perp}+q \varphi\right)^{3} \varphi d s .
$$

By Lemma 3 by $v_{0}^{\perp}$ and $r_{0}$, we construct $w_{0}^{\perp}$ and $q_{0}$. Put $v_{0}=v_{0}^{\perp}+r_{0} \varphi$ and $w_{0}=$ $w_{0}^{\perp}+q_{0} \varphi$, then $u_{0}=\left(v_{0}, w_{0}\right) \in \mathfrak{M}$.

Theorem 1. Let $\alpha_{2}, \kappa_{2} \in \mathbb{R}_{+}, n \leq 4, \beta_{2} \in\left(0, \alpha_{2} \nu_{1}\right)$, or $\beta_{2}=\alpha_{2} \nu_{1}, q^{2}\|\varphi\|_{L_{4}}^{4}+$ $2 q \int_{\Omega} w^{\perp} \varphi^{3} d s+\int_{\Omega}\left(w^{\perp}\right)^{2} \varphi^{2} \neq 0$, then the set $\mathfrak{M}$ at the point $u_{0}$ is a simple Banach $C^{\infty}$ manifold.

The second equation of system (9) can be represented as:

$$
q^{3}\|\varphi\|_{L_{4}(\Omega)}^{4}+3 q^{2} \int_{\Omega} w^{\perp} \varphi^{3} d s+3 q \int_{\Omega}\left(w^{\perp}\right)^{2} \varphi^{2} d s+\int_{\Omega} \varphi\left(w^{\perp}\right)^{3} d s+\kappa_{2} r=0 .
$$

The equation (10) is a cubic equation of general form $a q^{3}+b q^{2}+c q^{2}+d=0$ with respect to $q$. According to Cardano formulas, any cubic equation of general form with the help of replacement $q=y-\frac{b}{3 a}$ can be reduced to canonical form $y^{3}+p y+e=0$ with coefficients

$$
\begin{gathered}
a=\|\varphi\|_{L_{4}(\Omega)}^{4}, b=3 \int_{\Omega} w^{\perp} \varphi^{3} d s, c=3 \int_{\Omega}\left(w^{\perp}\right)^{2} \varphi^{2} d s, d=\int_{\Omega} \varphi\left(w^{\perp}\right)^{3} d s-\kappa_{2} r, \\
p=\frac{3 a c-b^{2}}{9 a^{2}}, e=\frac{1}{2}\left(\frac{2 b^{3}}{27 a^{3}}-\frac{b c}{3 a^{2}}+\frac{d}{a}\right), Q=p^{3}+e^{2} .
\end{gathered}
$$


By virtue of the already mentioned Cardano formulas, Theorem 1 and Theorem on the existence of a solution of problem $(5),(6)[8,10]$ is valid.

Theorem 2. For any $u_{0}=\left(v_{0}, w_{0}\right) \in \mathfrak{H}, n \leq 4, \alpha_{2}, \kappa_{2} \in \mathbb{R}_{+}$and

(i) $\beta_{2} \in\left(0, \alpha_{2} \nu_{1}\right)$ there exists a unique solution to problem (2) - (4);

(ii) $\beta_{2}=\alpha_{2} \nu_{1}, Q>0$ there exists a unique solution to problem (2) - (4);

(iii) $\beta_{2}=\alpha_{2} \nu_{1}, Q=0$ and following condition is fulfilled

$$
q^{2}\|\varphi\|_{L_{4}(\Omega)}^{4}+2 q \int_{\Omega} w^{\perp} \varphi^{3} d s+\int_{\Omega}\left(w^{\perp}\right)^{2} \varphi^{2}=0
$$

there exists two solutions to problem (2) - (4);

(iv) $\beta_{2}=\alpha_{2} \nu_{1}, Q<0$ there exists three solutions to problem (2) - (4).

The authors would like to thank Professor G.A. Sviridyuk for the support and given opportunities.

The work was supported by Act 211 Government of the Russian Federation, contract no. 02.A03.21.0011.

\section{References}

1. Fitz Hugh R. Mathematical Models of Threshold Phenomena in the Nerve Membrane. Bulletin of Mathematical Biology, 1955, vol. 17, no. 4, pp. 257-278.

2. Nagumo J., Arimoto S., Yoshizawa S. An Active Pulse Transmission Line Simulating Nerve Axon. Proceedings of the IRE, 1962, vol. 50, no. 10, pp. 2061-2070.

3. Pesin Ya.B., Yurchenko A.A. Some Physical Models Described by the Reaction-Diffusion Equation, and Coupled Map Lattices. Russian Mathematical Surveys, 2004, vol. 59, no. 3, pp. $481-513$.

4. Glyzin S.D., Kolesov A.Yu., Rozov N.Kh. On a Modification of the FitzHugh-Nagumo Neuron Model. Computational Mathematics and Mathematical Physics, 2014, vol. 54, no. 3, pp. 443-461. DOI: 10.1134/S0965542514030063

5. Manakova N.A., Gavrilova O.V. Optimal Control for a Mathematical Model of Nerve Impulse Spreading. Bulletin of the South Ural State University. Series: Mathematical Modelling, Programming and Compute Software, 2015, vol. 8, no. 4, pp. 120-126. (in Russian) DOI: $10.14529 / \mathrm{mmp} 150411$

6. Gavrilova O.V. Start Control and Final Observation Problem for the Fitz Hugh-Nagumo System for the Dirichlet-Showalter-Sidorov Condition. Bulletin of the South Ural State University. Series: Mathematics. Mechanics. Physics, 2018, vol. 10, no. 3, pp. 12-18. (in Russian) DOI: $10.14529 / \mathrm{mmph} 180302$

7. Bokareva T.A., Sviridyuk G.A. Whitney Folds of the Phase Spaces of Some Semilinear Equations of Sobolev Type. Mathematical Notes, 1994, vol. 55, no. 3-4, pp. 237-242. DOI: $10.1007 / \mathrm{BF} 02110776$

8. Sviridyuk G.A. Phase Portraits of Sobolev-Type Semilinear Equations with a Relatively Strongly Sectorial Operator. St. Petersburg Mathematical Journal, 1995, vol. 6, no. 5, pp. 1109-1126.

9. Sviridyuk G.A., Kazak V.O. The Phase Space of a Generalized Model of Oskolkov. Siberian Mathematical Journal, 2003, vol. 44, no. 5, pp. 877-882. DOI: 10.1023/A:1026080506657

10. Manakova N.A., Sviridyuk G.A. Nonclassical Equations of Mathematical Physics. Phase Space of Semilinear Sobolev Type Equations. Bulletin of the South Ural State University. Series: Mathematics. Mechanics. Physics, 2016, vol. 8, no. 3, pp. 31-51. (in Russian) DOI: $10.14529 / \mathrm{mmph} 160304$ 
11. Sviridyuk G.A. Quasistationary Trajectories of Semilinear Dynamical Equations of Sobolev Type. Russian Academy of Sciences. Izvestiya Mathematics, 1994, vol. 42, no. 3, pp. 601-614.

12. Sviridyuk G.A., Zagrebina S.A. The Showalter-Sidorov Problem as a Phenomena of the Sobolev Type Equations. The Bulletin of Irkutsk State University. Series: Mathematics, 2010, vol. 3, no. 1, pp. 104-125. (in Russian)

13. Sviridyuk G.A., Karamova A.F. On the Phase Space Fold of a Nonclassical Equation. Differential Equations, 2005, vol. 41, no. 10, pp. 1476-1481. DOI: 10.1007/s10625-005-0300-5

14. Gilmutdinova A.F. On Nonuniqueness of Solutions to the Showalter-Sidorov Problem for the Plotnikov Model. Vestnik of Samara University. Natural Science Series, 2007, no. 9, pp. 85-90. (in Russian)

15. Gajewski H., Gröger K., Zacharias K. Nichtlineare Operatorgleichungen und Operatordifferentialgleichungen. Berlin, Akademie, 1974. (in German)

Received May 15, 2018

УДК 517.9

DOI: $10.14529 / \mathrm{mmp} 180413$

\title{
О НЕЕДИНСТВЕННОСТИ РЕШЕНИЙ ЗАДАЧИ ШОУОЛТЕРА - СИДОРОВА ДЛЯ ОДНОЙ МАТЕМАТИЧЕСКОЙ МОДЕЛИ РАСПРОСТРАНЕНИЯ НЕРВНОГО ИМПУЛЬСА В МЕМБРАНЕ
}

\author{
Н.А. Манакова ${ }^{1}$, О.В. Гаврилова ${ }^{1}$ \\ ${ }^{1}$ Южно-Уральский государственный университет, г. Челябинск, \\ Российская Федерация
}

\begin{abstract}
Статья посвящена изучению морфологии фазового пространства математической модели распространения нервного импульса в мембране, основанной на вырожденной системе уравнений Фитц Хью - Нагумо, заданной на ограниченной области с гладкой границей. В данной математической модели скорость изменения одной из компонент системы может значительно превосходить другую, что приводит к вырожденной системе уравнений Фитц Хью - Нагумо. Изучаемая модель относится к широкому классу полулинейных моделей соболевского типа. Для исследования вопроса неединственности решений задачи Шоуолтера - Сидорова будет использован метод фазового пространства, который был разработан Г.А. Свиридюком для исследования разрешимости уравнений соболевского типа. Нами будет показано, что фазовое пространство исследуемой модели содержит особенности типа складки Уитни и выявлены условия существования, единственности или множественности решений задачи Шоуолтера Сидорова в зависимости от параметров системы.
\end{abstract}

Ключевые слова: уравнения соболевского типа; задача Шоуолтера - Сидорова; система уравнений Фити Хъю - Нагумо; неединственность решений.

\section{Литература}

1. Fitz Hugh, R. Mathematical Models of Threshold Phenomena in the Nerve Membrane / R. Fitz Hugh // Bulletin of Mathematical Biology. - 1955. - V. 17, № 4. - P. 257-278.

2. Nagumo, J. An Active Pulse Transmission Line Simulating Nerve Axon / J. Nagumo, S. Arimoto, S. Yoshizawa // Proceedings of the IRE. - 1962. - V. 50, № 10. - P. 2061-2070.

Вестник ЮУрГУ. Серия «Математическое моделирование

и программирование» (Вестник ЮУрГУ ММП). 2018. Т. 11, № 4. С. 161-168 
3. Pesin, Ya.B. Some Physical Models Described by the Reaction-Diffusion Equation, and Coupled Map Lattices / Ya.B. Pesin, A.A. Yurchenko // Russian Mathematical Surveys. 2004. - V. 59, № 3. - P. 481-513.

4. Glyzin, S.D. On a Modification of the FitzHugh - Nagumo Neuron Model / S.D. Glyzin, A.Yu. Kolesov, N.Kh. Rozov // Computational Mathematics and Mathematical Physics. 2014. - V. 54, № 3. - P. 443-461.

5. Манакова, Н.А. Оптимальное управление для одной математической модели распространения нервного импульса / Н.А. Манакова, О.В. Гаврилова // Вестник ЮУрГУ. Серия: Математическое моделирование и программирование. - 2015. - Т. 8, № 4. C. $120-126$.

6. Гаврилова, О.В. Задача стартового управления и финального наблюдения для системы уравнений Фитц Хью - Нагумо с условием Дирихле - Шоуолтера - Сидорова / О.В. Гаврилова // Вестник ЮУрГУ. Серия: Математика. Механика. Физика. - 2018. T. 10, № 3. - C. 12-18.

7. Бокарева, Т.А. Сборки Уитни фазовых пространств некоторых полулинейных уравнений типа Соболева / Т.А. Бокарева, Г.А. Свиридюк / / Математические заметки. - 1994. T. 55, № 3. - С. 3-10.

8. Свиридюк, Г.А. Фазовые пространства полулинейных уравнений типа Соболева с относительно сильно секториальным оператором / Г.А. Свиридюк // Алгебра и анализ. 1994. - Т. 6, № 2. - C. 252-272.

9. Свиридюк, Г.А. Фазовое пространство одной обобщенной модели Осколкова / Г.А. Свиридюк, В.О. Казак // Сибирский математический журнал. - 2003. - Т. 44, № 5. C. $1124-1131$.

10. Манакова, Н.А. Неклассические уравнения математической физики. Фазовые пространства полулинейных уравнений соболевского типа / Н.А. Манакова, Г.А. Свиридюк // Вестник ЮУрГУ. Серия: Математика. Механика. Физика. - 2016. - Т. 8, № 3. - С. 31-51.

11. Свиридюк, Г.А. Квазистационарные траектории полулинейных динамических уравнений типа Соболева / Г.А. Свиридюк // Известия АН СССР. Серия: Математическая. 1994. - Т. 57, № 3. - С. 192-207.

12. Свиридюк, Г.А. Задача Шоуолтера - Сидорова как феномен уравнений соболевского типа / Г.А. Свиридюк, С.А. Загребина // Известия Иркутского государственного университета. Серия: Математика. - 2010. - Т. 3, № 1. - С. 51-72.

13. Свиридюк, Г.А. О складке фазового пространства одного неклассического уравнения / Г.А. Свиридюк, А.Ф. Карамова // Дифференциальные уравнения. - 2005. - Т. 41, № 10. C. $1476-1581$.

14. Гильмутдинова, А.Ф. О неединственности решений задачи Шоуолтера - Сидорова для одной модели Плотникова / А.Ф. Гильмутдинова // Вестник СамГУ. - 2007. - № 9/1. C. $85-90$.

15. Гаевский, Х. Нелинейные операторные уравнения и операторные дифференциальные уравнения / Х. Гаевский, К. Грегер, К. Захариас. - М.: Мир, 1978.

Наталья Александровна Манакова, доктор физико-математических наук, доцент, кафедра «Уравнения математической физики», Южно-Уральский государственный университет (г. Челябинск, Российская Федерация), manakovana@susu.ru.

Ольга Витальевна Гаврилова, аспирант, кафедра «Уравнения математической физики», Южно-Уральский государственный университет (г. Челябинск, Российская Федерация), gavrilovaov@susu.ru.

Поступила в редакиию 15 мая 2018 г. 